\title{
Fungal Diversity of Maize (Zea Mays L.) Grains
}

\author{
"Kaspars Gulbis ${ }^{1 ; 2}$, Biruta Bankina', Gunita Bimšteina', Ingrīda Neusa-Luca', \\ Ance Roga ${ }^{3}$, Dāvids Fridmanis ${ }^{3}$ \\ ${ }^{1}$ Latvia University of Agriculture, Lielā street 2, Jelgava, LV-3001, Latvia \\ ${ }^{2}$ Latvian Plant Protection Centre, Ltd., Struktoru street 14a, Rīga, LV-1039, Latvia \\ ${ }^{3}$ Latvia Biomedical Research and Study Centre, Rātsupītes street 1, Rịga, LV-1067, Latvia
}

\begin{abstract}
Maize is becoming more and more important crop for dairy farming as forage and as substrate for biogas production. The mycotoxin producing fungi can spoil feed, reduce cattle productivity and cause health problems. The aim of this research was to study the mycoflora of maize grains in order to clarify the fungal composition and verify the presence of potential mycotoxin producing fungi. The grain samples were collected from different maize hybrid performance trial in Research and Study farm "Vecauce" of Latvia University of Agriculture in 2014. The fungi from 14 genera were isolated from surface sterilized grains. The most abundant were Alternaria, Fusarium and Penicillium spp. Mycotoxin producing fungi are present in maize grain mycoflora, and there is a risk that maize production can contain mycotoxins.
\end{abstract}

Key words: mycoflora, mycotoxins, Fusarium, ear rot, kernels.

\section{Introduction}

In Latvia, maize is important source for forage, mostly silage, some farmers are successful to harvest maize for grain despite the temperate climate. Significant part of maize production is used as substrate for biogas. According to data of Central Statistical Bureau of Latvia, the total area of maize in Latvia has increased rapidly during the last decade from less than 5 thousand to 20 thousand hectares. Maize is potentially high quality forage, but mycotoxin producing fungi can spoil the production. Mycotoxin contamination in feed can cause serious health and productivity problems to livestock, which can lead to significant losses for farmers. Also, mycotoxin residues from contaminated feed may appear in milk (Bennett \& Klich, 2003). Mycotoxins were produced by different fungi, including causal agents of ear rot.

In Europe, ear rot is most economically important maize disease, it can be caused by different fungi from Aspergillus, Penicillium, Diplodia, Nigrospora, Botryosphaeria, Cladosporium, Rhizoctonia and other genera (Medić-Pap, Maširević, \& Šofhauzer, 2011). However, the most important and harmful pathogens belong to Fusarium spp. (Czembor, Stępień, \& Waśkiewicz, 2014). There is inconsequence in the systematic of genus Fusarium, in some cases names of anamorph, but in other names of teleomorph were used. In this study names were used accordingly to Index
Fungorum (http://www.indexfungorum.org), but some important synonyms also were mentioned.

Gibberella zeae (F. graminearum) have been found common for maize and small grain cereals. In Latvia, G. zeae has been found by Treikale, Priekule, Javoisha, \& Lazareva in 2010 in wheat, and it can become a serious problem when maize is grown in crop rotation with wheat (Asran \& Buchenauer, 2003).

In Latvia, fungal mycoflora of maize grain or ears has not been studied before. The aim of this research was to study the mycoflora of maize grains in order to clarify the fungal composition and verify the presence of potential mycotoxin producing fungi under climatic conditions and agricultural technologies of Latvia.

\section{Materials and Methods}

Grain samples were collected in 2014 from different maize hybrid performance comparison trial in Research and Study farm "Vecauce" of Latvia University of Agriculture (latitude: N $56^{\circ} 28^{\prime}$, longitude: E $22^{\circ} 53^{\prime}$ ). In this trial, 26 different maize hybrids were arranged in randomized blocks with 4 replications, plot size $16.8 \mathrm{~m}^{2}$ (4 rows, $70 \mathrm{~cm}$ apart). Soil type in trial site was Calcaric Luvic Epigleyic Phazeozem (pH KCl 6.9, $\mathrm{P}_{2} \mathrm{O}_{5}-583 \mathrm{mg} \mathrm{kg}^{-1}, \mathrm{~K}_{2} \mathrm{O}-219 \mathrm{mg} \mathrm{kg}^{-1}$, organic matter $-3.0 \%$ ). Pre-crops in trial site were maize in 2013, sunflower in 2012 and maize in 2011 and 2010. Conventional soil tillage was used, crop residues were

\footnotetext{
* Corresponding Author's email: 
very well incorporated. Seeds were drilled on 6th May, seed density - 83000 seeds ha ${ }^{-1}$. The fungicides were not applied in this trial. Maize was harvested for silage on 6th October, average dry matter content was $33.5 \%$ and average yield $18.51 \mathrm{t} \mathrm{ha}^{-1}$.

From each plot 10 cobs were collected, from each cob 5 grains without visible fungal contamination were sampled. Surface of grains was sterilized with $1 \%$ sodium hypochlorite for one minute, rinsed three times in sterile distilled water. Grains placed onto petri dishes with streptomycin and penicillin enriched potato-dextrose agar (PDA). Plates were incubated at $+20{ }^{\circ} \mathrm{C}$ for $7-10$ days, subsequently, the obtained fungi were transferred to a new PDA or a specific medium. Fungi were identified either directly on the isolation plates (by the color and texture of mycelium and pigmentation of medium) or microscopically (by morphological characteristics of the spores and sporebearing structures). Obtained isolates were divided in morphologically similar groups and examples of each group were sequenced to confirm identification, all together 40 samples were sequenced.

The results of morphological identification were confirmed by sequencing of the ribosomal RNA gene Internal transcribed spacer (ITS) region and subsequent BLAST analysis of acquired DNA sequences against NCBI nucleotide database. The DNA extraction from fungal isolates was carried out by employment of NucleoMag $^{\circledR} 96$ Plant kit according to manufacturer's instructions (Macherey-Nagel, Germany). Prior extractions $\sim 10 \mu \mathrm{g}$ of fungal material were homogenized for $2 \times 60$ sec. using FastPrep ${ }^{\circledR}-24$ instrument and Lysing Matrix D (MP Biomedicals, USA) and supernatant phase of acquired lysate underwent phenol and chloroform treatment.

The amplification of ITS region by PCR was carried out for 40 cycles $\left(95^{\circ} \mathrm{C}-30 \mathrm{sec}, 57^{\circ} \mathrm{C}-30 \mathrm{sec}, 72{ }^{\circ} \mathrm{C}-30\right.$ sec, GeneAmp PCR System 9700 (Applied Biosystems, USA) in total volume of $12 \mu \mathrm{l}$. The reaction mixture was comprised of following components: $0.1 \mathrm{u}$ of HOT FIREPol ${ }^{\circledR}$ DNA Polymerase (Solis Biodyne, Estonia),
$1 \times \mathrm{BD}$ reaction buffer (Solis Biodyne, Estonia), 2.5 $\mathrm{mM} \mathrm{Mg} 2 \mathrm{Cl}$ (Solis Biodyne, Estonia), $0.2 \mathrm{mM}$ dNTP each (Thermo Fisher Scientific, USA), $0.3 \mu \mathrm{M}$ ITS4 (5'-TCCTCCGCTTATTGATATGC-3') - primer, 0.3 $\mu$ MITS5 (5'-GGAAGTAAAAGTCGTAACAAGG-3') primer (White et al, 1990) and $1 \mu 1$ of fungal DNA.

The success of the ITS region amplification was verified through the inspection of PCR products by agarose gel electrophoresis.

Positive reaction mixtures were cleaned up from excess of dNTPs and primers through employment of Exonuclease I $(0.5 \mu \mathrm{l})$ (Thermo Fisher Scientific, USA) and Shrimp Alkaline Phosphatase $(2 \mu \mathrm{l})$ (Thermo Fisher Scientific, USA) (incubated for $40 \mathrm{~min}$ at $37{ }^{\circ} \mathrm{C}$ and inactivated at $95^{\circ} \mathrm{C}$ for $20 \mathrm{~min}$ ). Further, $1 \mu 1$ of cleaned up fragment solution was transferred to BigDye ${ }^{\circledR}$ Terminator v3.1 Cycle Sequencing reaction mixture which was prepared according to the manufacturer's instructions (Applied Biosystems, USA). Both DNA strands of every PCR product were sequenced using ITS4 and ITS5 as primers and sequencing products were analyzed on 3130xl Genetic Analyzer (Applied Biosystems, USA).

All molecular biology related activities were carried out at "Genome center"- a genetic analysis core facility of Latvian Biomedical Research and Study center.

The Relative Density (RD) of fungal species and genera were calculated according to the method suggested by Broggi et al., 2007 and Tadych et al., 2012.

$$
\mathrm{RD}(\%)=\frac{\mathrm{ni}}{\mathrm{Ni}} \times 100
$$

$\mathrm{ni}$ - the number of genus or species isolated,

$\mathrm{Ni}$ - the total number of isolates.

\section{Results}

In total 2196 isolates were obtained. More than 50 morphologically different forms of fungi were isolated. In total 14 fungal genera were found.

The most abundant was fungi from genus Alternaria, the RD for this genus was $38 \%$ (Figure 1).

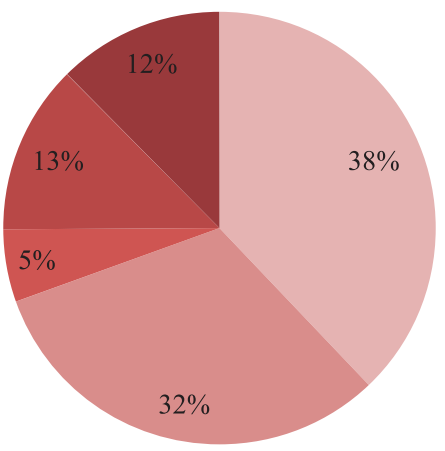

- Alternaria spp.

- Fusarium spp.

- Penicillium spp.

- Others

- Not specified

Figure 1. Proportion of fungal species in the mycoflora of maize grain. (Others - fungal spieces with $\mathrm{RD} \leq 3 \%$; Not specified - unidentified isolates) 
The RD for second most widespread fungal genus Fusarium was 32\%. Relative density for genus Penicillium was much lower - 5\%. RD for all other 11 fungal genera together was almost $13 \%$. In this group RD was from $0.05 \%$ up to $3 \%$. But $12 \%$ (273 isolates) haven't been identified yet. The RD of endophytic fungal genera Sarocladium and Trichoderma was 3\% and 2\%, respectively. The RD for Microdochium bolleyi was
2\%. RD for fungi from Epicoccum spp. was $1.5 \%$. The RD $1 \%$ and below was for Bipolaris spp., Chaetomium spp., Cladosporium spp., Sclerotinia spp., Nigrospora spp., Trichothecium spp., Lecanicillium spp.

Five species of Fusarium were identified. In this study, the majority (38\%) of all Fusarium isolates was G. zeae (Figure 2).

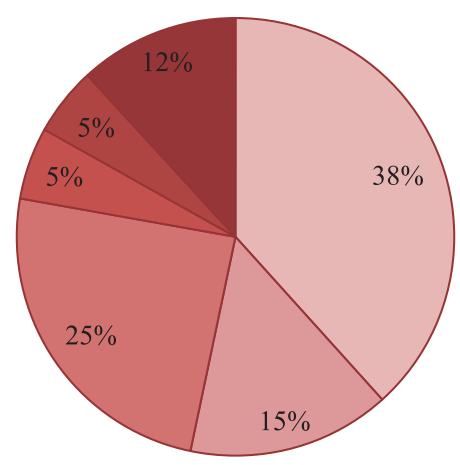

$\square$ F. graminearum

$\square$ F. sporotrichioides

$\square$ F. equiseti

- F. poae

- F. subglutinans

- Others

Figure 2. Proportion of Fusarium spp. Isolates.

The second most widespread fungi was Gibberella intricans ( $F$. equiseti), 25\% of Fusarium isolates belonged to this genus. Smaller share in proportion was for F. sporotrichioides, F. poae and Gibberella fujikuroi (F. subglutinans).

\section{Discussion}

Four major mycotoxin producing genera associated with maize are Alternaria, Fusarium, Penicillium and Aspergillus (Mansfield, 2005).

Fusarium spp. are the most frequently occurring fungi in temperate climates. Pathogens from Fusarium spp. are common for maize and small grain cereals. In Latvia, the maize is often grown in crop rotation with small grain cereals. Therefore, there is a risk that infection level of Fusarium spp. can become high in maize and in the whole crop rotation (Asran \& Buchenauer, 2003).

In maize grains a variety of Fusarium species is even greater than in cereals. In this current study the relative density for five different species of Fusarium was higher than $5 \%$. The most abundant was fungi from species G. zeae (RD 38\%). These fungi have been found on wheat in Latvia, too. In studies carried out in Czech Republic, Switzerland and Italy the G. zeae wasn't so abundant. In Czech Republic and Switzerland (silage), $19.8 \%$ and $16 \%$ respectively of isolated Fusarium spp. was G. zeae. (Eckard et al., 2011; Nedělník, Lindušková, \& Kmoch, 2012).

The second most widespread fungi in this study $G$. intricans $(25 \%)$ is not between most frequently isolated fungi in other studies. For instance, in the study carried out in Italy $8 \%$ of all Fusarium isolates were F. equiseti
(Logrieco et al., 1995). F. equiseti was between less widespread fungi in the study carried out in Switzerland, but in Czech Republic it was not reported at all. (Vogelgsang, 2011; Nedělník, Lindušková, \& Kmoch, 2012).

In this study, RD for F. sporotrichioides was $15 \%$, which is much more than reported in Czech Republic on maize grains $(1.3 \%)$. The F. sporotrichioides has been reported to be more widespread on maize silages. (Cheli, Campagnoli, \& Dell'Orto, 2013) For example, in Switzerland where Fusarium fungi were isolated from silage, $16 \%$ were $F$. sporotrichioides. (Wettstein, Forrer, \& Vogelgsang, 2011).

Relative density in this study for $F$. poae was $5 \%$, and it corresponds to results in other studies. In the study carried out in Czech Republic, it was 9.3\%. In the study carried out in Switzerland, $4.3 \%$ of isolated fungi from silage were $F$. poae.

$\mathrm{RD}$ in this study for G. fujikuroi was the same as for $F$. poae - 5\%, but in the study carried out in Czech Republic G. fujikuroi were the most abundant fungi (40.4\%) (Nedělník, Lindušková \& Kmoch, 2012). In the study carried out in Italy, the share of G. fujikuroi was from 6 to $27 \%$ depending on a year and farming system. (Lazzaro, et al., 2015).

It is interesting to note that one of the dominant species in other studies $F$. verticillioides was not found in this study. (Eckard et al., 2011; Nedělník, Lindušková, \& Kmoch, 2012; Lazzaro et al., 2015).

Most Fusarium spp. found in this study also has been found in other studies in other countries. Abundance of Fusarium species is variable between sites 
and years even in one region. (Eckard et al., 2011; Lazzaro et al., 2015). If compared this to other trials, it is possible to find common tendencies in proportion of fungal composition with this study (Eckard et al., 2011; Nedělník, Lindušková, \& Kmoch, 2012).

In this study, the most frequently isolated were fungi from Alternaria spp. Fungi from genera Alternaria has been reported to produce a wide range of mycotoxins; however, Alternaria, spp. includes also endophytic fungi (Ostry, 2008). As Alternaria toxins are supposed to be less harmful than toxins produced by Fusarium and Aspergillus species they haven't been studied so much (Ostry, 2008; Logrieco, Moretti, \& Solfrizzo, 2009).

Penicillium spp. is often isolated from maize, and it was also present in current study. Penicillium spp. has been considered as storage fungi; however, in many cases it is present on maize before harvest (Mansfield, Jones \& Kuldau, 2008). In the study carried out in Italy, the RD for Penicillium in organic maize was lower than $2 \%$. In this current study, the RD for Penicillium spp. was 5\%. (Lazzaro, Moretti, Giorni, Brera, \& Battilani, 2015).

Less frequently isolated in the current study was fungi from Epicoccum and Sarocladium spp. Epicoccum spp. includes both endophytes and pathogens and fungi from Sarocladium spp. has been reported as endophytes, which can deter the growth of maize pathogens such as $F$. verticillioides and Aspergillus flavus (Summerbell \& Scott, 2015)

Aspergillus spp. are worldwide distributed and able to produce the most toxic mycotoxins aflatoxins. Recently the presence of Aspergillus spp. in maize grain mycoflora has been found in European countries where it had not been a problem before, e.g. Croatia, Serbia, Slovenia, Romania and Northern Italy (Giorni, Magan, Pietri, Bertuzzi, \& Battilani, 2007; Szőke et al., 2013). In Italy, in the study carried out by Lazzaro, Moretti, Giorni, Brera, \& Battilani (2015) in 2010 and 2011 the RD for Aspergillus was low or it was not found at all. In this study, the Aspergillus spp. was not found.

The results obtained in this study correspond to results from other studies around Europe. Other studies reveal that fungal mycoflora is influenced by the site and year; therefore, it is important to continue the current research and monitor the situation. (Logrieco, Moretti, Ritieni, Bottalico, \& Corda, 1995; Eckard, Wettstein, Forrer, \& Vogelgsang, 2011; Nedělník, Lindušková, Kmoch, 2012).

\section{Conclusions}

The fungi from Alternaria, Fusarium and Penicillium spp. were most frequently isolated from maize grain in this study. These three genera are potential mycotoxin producers. The majority of all Fusarium isolates was $G$. zeae (38\%), the second most widespread fungi was $G$. intricans $(25 \%)$, a smaller share in proportion was for F. sporotrichioides, F. poae and G. fujikuroi. The potential mycotoxin producing fungi were present in maize grain samples without visible symptoms of fungal contamination collected from different maize hybrid performance comparison trial in Research and Study farm "Vecauce" of Latvia University of Agriculture in 2014. There is a risk that maize production can contain mycotoxins. Therefore, it is important to continue research.

Acknowledgements
Research was partly funded by the National Research Program Agricultural Resources for Sustainable Production of Qualitative and Healthy Foods in Latvia AgroBioRes subproject Sustainable use of soil resources and abatement of fertilization risks (SOIL).

\section{References}

1. Asran, M. R., \& Buchenauer, H. (2003). Pathogenicity of Fusarium graminearum isolates on maize (Zea mays L.) cultivars and relation with deoxynivalenol and ergosterol contents. Journal of Plant Diseases and Protection. 110 (3), 209-219.

2. Bennett, J. W., \& Klich, M. (2003). Mycotoxins. Clinical Microbiology Reviews. 16(3), 497-516. DOI:10.1128/CMR.16.3.497-516.2003.

3. Broggi, L. E., González, H. H. L., Resnik, S. L., \& Pacin, A. (2007). Alternaria alternata prevalence in cereal grains and soybean seeds from Entre Ríos, Argentina. Revista Iberoamericana de Micología, 24(1), 47-51.

4. Cheli, F., Campagnoli, A., \& Dell'Orto, V. (2013). Fungal populations and mycotoxins in silages: From occurrence to analysis. Animal Feed Science and Technology, 183(1-2), 1-16.
5. Czembor, E., Stępień, Ł., \& Waśkiewicz, A. (2014). Fusarium temperatum as a New Species Causing Ear Rot on Maize in Poland. Plant Disease. 98(7), 1001. DOI:10.1094/PDIS-11-13-1184-PDN.

6. Eckard, S., Wettstein, F., Forrer, H., \& Vogelgsang, S. (2011). Incidence of Fusarium species and mycotoxins in silage maize. Toxins (Basel). 3(8), 949-967. DOI: 10.3390/toxins3080949.

7. Giorni, P., Magan, N., Pietri, A., Bertuzzi, T., \& Battilani, P. (2007). Studies on Aspergillus section Flavi isolated from maize in northern Italy. International Journal of Food Microbiology. 113(3), 330-8. DOI: 10.1016/j.ijfoodmicro.2006.09.007.

8. Lazzaro, I., Moretti, A., Giorni, P., Brera, C., \& Battilani, P. (2015). Organic vs conventional farming: Differences in infection by mycotoxinproducing fungi on maize and wheat in Northern and Central Italy. Crop Protection. 72, 22-30. 
DOI:10.1016/j.cropro.2015.03.001.

9. Logrieco, A., Moretti, A., Ritieni, A., Bottalico, A., \& Corda, P. (1995). Occurrence and toxigenicity of Fusarium proliferatum from preharvest maize ear rot, and associated mycotoxins, in Italy. Plant Disease (USA). 79, 727-731.

10. 10. Logrieco, A., Moretti, A., \& Solfrizzo, M. (2009). Alternaria toxins and plant diseases: an overview of origin, occurrence and risks. World Mycotoxin Journal. 2(2), 129-140. DOI:10.3920/ WMJ2009.1145.

11. Mansfield M. A. (2005) Fungi and Mycotoxins in Fresh and Ensiled Maize and the Affects of Agronomic Practices, Weather Conditions and Silage Characteristics on Toxin Contamination. Doctoral dissertation, The Pennsylvania State University, Pennsylvania, United States.

12. Mansfield, M. A., Jones, A. D., \& Kuldau, G. A. (2008). Contamination of fresh and ensiled maize by multiple penicillium mycotoxins. Phytopathology. 98(3), 330-336. DOI:10.1094/PHYTO-98-3-0330.

13. Medić-Pap, S. S., Maširević, S. N., \& Šofhauzer, I. P. (2011). Mycoflora of commercial maize seed in 2010. Zbornik Matice Srpske Za Prirodne Nauke. 120, 129-135. DOI:10.2298/ZMSPN1120129M.

14. Nedělník, J., Lindušková, H., \& Kmoch, M. (2012) Influence of growing Bt maize on Fusarium infection and mycotoxins content - a review. Plant Protect. Sci. 48, 18-24.

15. Ostry, V. (2008). Alternaria mycotoxins: an overview of chemical characterization, producers, tox- icity, analysis and occurrence in foodstuffs. World Mycotoxin Journal, 1(2), 175-188. DOI:10.3920/ WMJ2008.x013.

16. Summerbell, R. C., \& Scott, J. A. (2015) Acremonium. In R. Russell, M. Paterson \& N. Lima (Eds.), Molecular Biology of Food and Water Borne Mycotoxigenic and Mycotic Fungi (pp. 115-128). Boca Raton, Florida: CRC Press.

17. Szőke, C., Bónis, P., Árendás, T., Szécsi, Á., Marton, C. L., Marton, L. C. \& Spitkó, T. (2013). Occurrence of aflatoxin producing Aspergillus flavus isolates in maize kernel in Hungary. In 60 Years of Hungarian Hybrid Maize 1953-2013, 14 November 2013 (pp. 126-130), Hungary, Martonvásár: Pannonian Plant Biotechnology Association.

18. Tadych, M., Bergen, M. S., Johnson-Cicalese, J., Polashock, J. J., Vorsa, N., \& White, J. F. (2012). Endophytic and pathogenic fungi of developing cranberry ovaries from flower to mature fruit: diversity and succession. Fungal Diversity, 54(1), 101-116. DOI:10.1007/s13225-012-0160-2.

19. Treikale, O., Priekule, I., Javoisha, B., \& Lazareva, L. (2010). Fusarium head blight: distribution in wheat in Latvia. Communications in Agricultural and Applied Biological Sciences. 75(4), 627-634.

20. White, T. J., Bruns, T., Lee, S., \& Taylor, J. W. (1990). Amplification and direct sequencing of fungal ribosomal RNA genes for phylogenetics. In Innis, M. A., Gelfand, D. H, Sninsky, J. J., and White, T. J. (Eds.), PCR Protocols: A Guide to Methods and Applications (pp. 315-322), New York: Academic Press, Inc. 